\title{
Genome ethics chair resigns amid worries over autonomy
}

San Francisco. Lori Andrews, the chair of a working group set up jointly by the US National Institutes of Health $(\mathrm{NIH})$ and the Department of Energy (DOE) to provide advice on the ethical, legal and social implications of the Human Genome Project, has resigned, citing concern about the autonomy of the group.

The working group was set up to advise Congress, President Bill Clinton and the public on the implications of the \$3-billion gene-sequencing project. It is funded through the National Center for Human Genome Research (NCHGR), although separately from the 5 per cent which is set aside for so-called ELSI (ethical, legal and social implications) research grants.

Various members of the working group have recently been expressing frustration about interference by NCHGR. Their main complaint is that, over the past year or so, the centre has become increasingly involved in the working group's budget allocation and position statements.

At the centre of the dispute, they claim, is the working group's responsibility for representing a range of diverse interests - from geneticists to consumer advocates - which can conflict with the more focused concerns of scientists engaged in mapping and sequencing the human genome.

At a meeting with Francis Collins, director of the NCHGR, on 25 January, the executive committee of the working group urged him to reduce the involvement of his staff in assessing the working group's activities and in representing ELSI policy interests in Washington. But Collins - who was not available for comment this week - is said to have proposed merely that NCHGR should deal with day-to-day policy matters while the working group addresses longer-term issues.

Some observers suggest that Collins may have been reacting to perceptions that the working group has had difficulty in persuading legislators to enact policies related to the human genome. New measures on issues such as privacy and discrimination could be critical both to the genome project's longterm viability and to its public acceptability.

David Cox, co-director of the Stanford Human Genome Center, and a member of the working group, says that both NCHGR and the working group should be able to pursue policy issues. But he says that because of its composition, the group may have to move more cautiously than NCHGR staff.

Paul Billings, acting associate professor of medicine at Stanford University, says that the ELSI working group has already proved its effectiveness in cases such as a suit filed recently against the Department of
Defense's DNA Specimen Repository (see Nature 379, 385; 1996). In that case, ELSIfunded research provided the ammunition for negotiations about procedures for obtaining proper consent, confidentiality and other restrictions on genetic information storage.

The immediate trigger for the disagreement leading to the departure of Andrews, who is professor of law at the University of Chicago, appears to have been concern among working group members about behavioural genetics. The group had planned to spend $\$ 20,000$ on developing an anthology on the "non-medical uses of genetic information", later renamed as a collection of papers on behavioural genetics.

But NCHGR told the working group that such a project would be too expensive. When the group prepared a statement last year on the arguments linking race and intelligence put forward by Richard Herrnstein and Charles Murray in their book, The Bell Curve, it was held up for eight months while it went through a series of reviews (see Nature 378, 529; 1995).

Troy Duster, professor of sociology at the University of California, Berkeley, and vicechair of the working group, says that the call for papers for the planned collection may have been squashed partly because of concern among geneticists working on behavioural issues that the working group would put together a general attack on their area of research.

In a memorandum sent last week to committee members, Duster wrote that, as a member of the National Advisory Council for Human Genome Research, he had found it "impossible to reconcile ' $\$ 12$ million to this lab' and ' $\$ 8$ million to that lab' with the working group's possible allotment of $\$ 25,000$ ", adding that this was "transparently insufficient funding to pursue the ethical, legal and social issues of the nonmedical uses of genetic information". In addition, NCHGR cut the working group's budget by 5 per cent in the current fiscal year, and limited its activities to one ELSI meeting.

Andrews' resignation came as the working group's task force on genetic testing prepares to release for public comment draft principles for the delivery of genetic tests. Duster, who has stepped in as Andrews' temporary replacement, says that he has no interest in chairing the working group in the current circumstances. He adds that decision-making authority over its overall budget, its allocations of grants, working group projects and group policy statements, must be clarified. "We have to be autonomous," says Duster.

Sally Lehrman
Pollution inspectors 'inconsistent' about radioactive material

London. The British government's radioactive waste management advisory committee (RWMAC) has criticized its pollution inspectorate for adopting a rigid - and sometimes inconsistent - attitude to the use, storage and disposal of small amounts of radioactive materials. This has led to a 12-fold increase in prosecutions in the space of a year, the committee suggests.

The number of prosecutions of these "small users" of radioactive materials, mainly universities and hospitals, pursued by Her Majesty's Inspectorate of Pollution (HMIP) increased from one a year between 1989 and 1991, to 12 in the year 1991-92. Fifteen users were prosecuted in 1994-95.

In a report on the problems encountered by such users, RWMAC, a 20-member group chaired by Sir Gordon Beveridge, vice-chancellor of Queen's University, Belfast, said it found evidence of inconsistencies in the way safety regulations were enforced. It doubted that the sharp rise in prosecutions was entirely the fault of operators . "A decision to prosecute more readily seems the most likely explanation."

The advisory committee, in a chapter entitled "Attitude of inspectors: diplomatic relations restored?", criticizes the inspectorate for sending inexperienced and inadequately trained staff. It also cites complaints from users who said inspectors tended to be uncooperative and unwilling to dispense advice. It calls for the reinstatement of specialist inspectors, the setting up of a users' help desk, and adoption by HMIP of a more "pragmatic approach" towards resolving problems.

The report cites several examples of inconsistencies in enforcement. In one case, a small user was prosecuted for inadvertently disposing of small amounts of radioactive clinical waste in an appropriate incinerator, but one he was not authorized to use. But another user who disposed of radioactive waste in an incinerator that was not authorized for such disposal received only an enforcement notice. The committee says it is essential for an enforcement action to relate to the level of offence. "Otherwise a perverse incentive might be created to cover up rather than to own up."

The report acknowledges "evidence of at least some relaxation in the attitude and approach" of the inspectorate towards understanding the problems of small users. But it adds that many problems still remain. These include a lack of appropriate sites where small users can accumulate, store and dispose of radioactive waste, insufficient incinerators and landfill sites, excessive paperwork, and high administrative charges.

Ehsan Masood 